\title{
The relationship between Iranian EFL teachers' emotional intelligence and their teaching styles
}

\author{
Mousapour, Giti \\ Sistan and Bluchestan University, Iran (mousapour@hamoon.usb.ac.ir)
}

Khorram, Alireza $\bowtie$

Sistan and Bluchestan University, Iran (a.khorram2014@gmail.com)

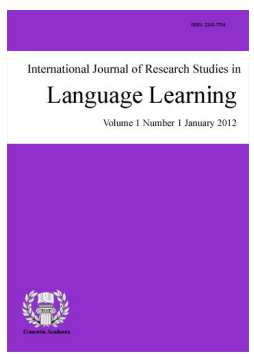

ISSN: 2243-7754 Online ISSN: 2243-7762

OPEN ACCESS

\section{Abstract}

The present study tried to find out the relationship between Iranian EFL teachers' emotional intelligence and their teaching styles. Moreover, it tried to explore the components of emotional intelligence that could act as predictors for Iranian EFL teachers' teaching styles. The participants of this study were 90 Iranian EFL teachers from Sistan and Baluchestan high schools and language institutes. Bar-On Emotional Quotient questionnaire and Grasha's Teaching Styles Inventory (TSI) questionnaire were employed as instruments of this study. The findings of the study revealed that there was a positive strong significant correlation between Iranian EFL teachers' emotional intelligence and their teaching styles. The components of emotional intelligence that can act as predictors for teachers' teaching styles were explored. Out of five components of emotional intelligence, four components (interpersonal, intrapersonal, adaptability, and stress management) could act as predictors for teachers' teaching style.

Keywords: emotional intelligence; teaching styles, Iranian EFL teachers 


\section{The relationship between Iranian EFL teachers' emotional intelligence and their teaching styles}

\section{Introduction}

Teaching must be observed as an emotional endeavor, yet more so known its position as a assisting or concerning profession (Hargreaves, 1998; Hargreaves \& Tucker, 1991). Hargreaves (1998) utters in other word, as an emotional performs teaching triggers, and states teachers' own thoughts and the proceedings in which those thoughts are implanted. As well the, as an emotional perform, teaching triggers, and if not influences the feelings and actions of those with whom teachers occupation and shape relationships (p. 838). The expertise with which teachers employ such behaviors describes their teaching styles. Consideration shapes usually are urbanized to permit students and others to assess ability presentation in order to provide teachers comment and to permit assessment amongst ability to be completed (Seldin, 1984; McKeachie, 1994).

Latest studies about teacher thoughts styles, for instance, have demonstrated that teacher's emotional relations with their students manipulate lots of their assessments about instructive satisfied, syllabus, and pedagogy (Hargreaves, 2000a; McCaughtry, 2004 \& Rosiek, 2003). McCaughtry (2004) understood that the majority of teaching assessments are completed at least fairly in relation to how teachers understand student's emotional lives. The procedure that teachers modify their thoughts and apply is regularly emotional. It is engaged with problems, outgoing tide and runs, examination and mistake, mystification, disappointment, happiness, and achievement. Hargreaves (2000a, 2000b) lately supplied a theoretical structure for drawing what he describes "emotional geographies" of teaching and teacher revolutionize. He acknowledged five emotional geographies that "involve the spatial and experimental models of convenience and/or remoteness in human communications and associations that assist generate, construct and paint the feelings and emotions we practice about ourselves, our earth, and every one" (Hargreaves, 2000b, p. 815). By paying attention to (Hargreaves, 2000a), these geographies are undoubtedly not equally restricted and should be observed cooperatively and in arrangement as a heuristic for accepting how teacher's emotional feelings about teaching and revolutionize _are predisposed by their corporeal surroundings, schools as institutes, the societal performance of learning, and wider societal services that allow and restrain schooling. For this study, Hargreaves (2000a) recognized emotional geographies as:

Socio-cultural geographies, which embrace such topics as contest, group of pupils, sexual category, sexualities, urbanization, capability/inability, and others that manipulate the emotional considerate that teachers have of their occupation.

$>\quad$ Moral geographies, in which teacher's basic principles and attitude about education and the rationales of their occupation face up to the actualities of daily classrooms and other friends.

$>\quad$ Professional geographies, in which descriptions of the "specialized" (e.g., manifestation, performance, associations with classmates, involvement in specialized institutes) are consulted and performed.

$>$ Political geographies, which are positions and communications in which school, region, situation, and public technical services form teacher's programs, thoughts, and emotion.

$>$ Physical geographies, which contains the managerial preparation, conveniences, and tools that manipulate teacher's thoughts about their responsibility in learning.

A structure of emotional geographies is intended to emphasize the traditions that teacher's corporeal and societal civilization equally comprise their emotional viewpoints on alteration, which then provides increase to broader and richer clarifications for how teachers construct intelligence of their occupation and why they act the 
approach they accomplish to appreciate why some teachers and students results take place in convinced classrooms and not others or why alter can appear so diverse across varied frameworks, it is significant to recognize the intuitive stage of emotion and feeling that permeates teacher's occupation in their different and varied frameworks (Hargreaves, 2000a).

\subsection{Statement of the Problem and Purpose of the Study}

Among the different factors that are related to use of emotional intelligence, teaching styles are very important. The relationship between Iranian EFL teachers' emotional intelligence and their teaching styles will be explored in this study. Therefore, the exact problem is the relationship between Iranian EFL teachers' emotional intelligence and their teaching styles. Discussion on teachers' emotional intelligence and teaching styles in learning a second or a foreign language specially in creating tendency to learn independently needs further research. Hence, this study first, tries to find out if there is any statistically significant relationship between Iranian EFL teachers' emotional intelligence and their teaching styles. Secondly, this study attempts to explore components of emotional intelligence that can act as predictors for Iranian EFL teachers' teaching styles.

\subsection{Significance of the Study}

The selection of an appropriate teaching approach is important to success of teaching process. To be successful, teachers must learn how to use a variety of teaching strategies (Joyce \& Weil, 1986). According to Canfield (1976), research on learning and teaching styles can serve as a basis for selecting teaching approaches. Joyce and Weil (1986) proposed that students react differently to different teaching methods, and that selection of proper method is critical to learning style of those being served by instruction.

The findings of this research will revealed that emotional intelligence could help EFL teachers use the most appropriate teaching styles in their classroom and also behaved in a good way with their students and facilitated language learning. Emotional intelligence can increase students' ability to understand and perceive, because learning is an emotional process, so emotional intelligence is an important element in students' educational system. This study encourages education authorities, school managers and also students, to consider the emotional intelligence as an effective element for academic and career success. Education authorities can consider findings of this study for recruiting more effective teachers; school managers also benefit from the findings of this study to consider them in promoting teachers with more successful teaching styles. As mentioned before this study tried to consider the relationship between Iranian EFL teachers' emotional intelligence and their teaching styles will be explored in this study. It also considered the components of emotional intelligence that can act as a predicator for Iranian EFL teachers' teaching styles.

Research questions are as follows:

Q Q1: Is there any statistically significant relationship between Iranian EFL teachers' emotional intelligence and their teaching styles?

Q2: Can any component of emotional intelligence act as a predictor for Iranian EFL teachers' teaching styles (as a whole concept)?

\section{Literature Review}

\subsection{Emotional Intelligence}

The concept of emotional intelligence proposed by Salovey and Mayer (1990) was defined as "the skill to examine one's own and others' feelings and emotions, to distinguish between them and to employ this information to conduct one's philosophy and proceedings" (p. 189). Moreover, Ahuja (2011) cites the employees who can better understand themselves and others and be able to better manage their feelings and respond 
according to the situation will undoubtedly perform better in their jobs. The components of emotional were general mood, adaptability, stress management, interpersonal, and intrapersonal.

Azizian and Samadi (2011) determined the relationship between emotional intelligence (EI) and self-efficacy of the staff of the Hamedan Branch of Islamic Azad University. The results of this study revealed that there was a positive significant correlation between emotional intelligence (EI) and self-efficacy. Also it was understood that there was a positive significant correlation between self-awareness and self-efficacy and a positive significant correlation between self-control and self-efficacy. Furthermore, a positive significant correlation was explored between intimacy and self-efficacy and a positive significant correlation existed between social skills and self-efficacy. While, Shakib and Barani (2011) investigated the relationship between Iranian high school students' EQ (Emotional Quotient) level and their level of language proficiency; the participants of this study were 130 high school students in Gorgan. The instruments of this study were Nelson Proficiency Test and EQ Test. After homogenizing the scores of participants was decrease to 84. After that relationship between EQ scores and language proficiency scores were considered by using Pearson coefficient correlation. The results of this study showed that there was reliable and significant relationship between language proficiency and emotional intelligence. Besides, the relationship between students' EQ level and their level of language proficiency was stronger in females than males.

Gürol, Ozercan, and Yalcin (2010) examined the relationship between pre-service teachers' emotional intelligence and their self-efficacy. In addition, pre-service teacher differences on EI and self-efficacy beliefs were also investigated in this study by considering the gender of participants. The participants of present study were pre-service teachers who were selected from education faculty in Firat University. The results attained through using Pearson Product-Moment Correlation demonstrated that there was a positive significant correlation between perceived EI and self-efficacy $(r=0.5)$. This study supplied no support for gender differences in EI and self-efficacy. In addition, Ebrahimi Koohbanani (2013) determined the relationship between spiritual intelligence (SI) and emotional intelligence with life satisfaction (LS) among talented female high school students in Birjand. For this goal, 123 students were elected considering the Simple Sampling Method. The results of this discovered that there is generally no meaningful relationship between SI and LS, but there was a meaningful relationship between EI and LS. The results of regression analysis illustrated that "Moral Virtue" in SI and "Appraisal \& Expression of Emotion" and "Regulation of Emotion" in EI are meaningful predictors for LS. Also SI together with EI has a meaningful relationship with LS.

Pieterse and Quilling (2011) examined the impact of self-developed versus other-person-developed digital stories on emotional intelligence in learners, in Durban, South Africa. Participants of this study were four classes each of Grade 9's and Grade 10's. Experimental groups were exposed to an accurate digital story power containing making by their own, watching peer-created and public digital stories. Non-experimental classes practiced no involvement. The SSEIT trait emotional intelligence test administered to pre-test, midway, post-test and one school term after the end of the intervention, permitting longitudinal tracking of emotional intelligence test results. Results showed the impact of the making of digital story- telling, watching of peer and public digital stories on trait EI. It also signified how qualitative data presents more immediate information than quantitative data from the SSEIS test. However, the real writing of the test has revealed to be critical in pupils' evaluations of their experiences. The results of this study demonstrated teachers are able to proficiently use tools to encourage trait EI in the classroom.

\subsection{Teaching Styles}

Teaching style refers to all of teaching techniques and activities and approaches that a teacher employs in teaching a certain subject in the classroom (Cooper, 2001). The way teachers teach in the classroom has been found to be associated with teachers' personality (Cooper, 2001), their content knowledge (Mewborn 2001), their behavior in the class (Cotton, 2000), how they manage their classes (Yilmaz \& Çavaş, 2008), and even the context of teaching (Rahimi \& Nabilou, 2010). Teaching style applied in educational environments affects all 
The relationship between Iranian EFL teachers' emotional intelligence and their teaching styles

aforementioned affairs and performances. Teaching styles influence the character of the learners, learning environment, and overall execution of learning in a classroom.

Amir, Mohd Jelas, and Rahman (2011) considered the teaching and learning style of lecturers and students at Universiti Kebangsaan Malaysia. The participants of this study were 120 lecturers and 545 students. A translated version of Grasha-Riechman (1994), Teaching and Learning Style Inventories were used as an instruments of this study. Results of this study revealed that expert, facilitator and delegator teaching styles were dominant among lecturers while students are more dominant in collaborative and competitive learning styles. The implications of the findings are argued in terms of university teaching and learning to improve delivery systems and the outcomes of learning. The effect of two types of teaching style, i.e. teacher - oriented and learner - oriented ones on adjustment of students in three emotional, social and educational domains were investigated by Khandaghi and Farasat (2011). The participants of this study were 31 teachers and 300 students in fifth grade were elected by multi-stage cluster sampling in academic year of 2010-2011. The results of this study revealed that the mean scores of emotional, educational and social adjustments of students whose teachers employ an active teaching style more than students that their teachers employ an inactive teaching style. Also, there was a significant difference between the emotional and educational adjustments among the students who have two different kinds of active and inactive teaching styles. But its effect on social adjustment was not significantly different.

Another research was conducted to find the association between learning styles and teaching styles at undergraduate level in a business school by Hussain and Ayub (2012). Canfield Learning Styles Inventory (CLSI, 1992) and Staffordshire Evaluation of Teaching Styles (SETS, 2007) were employed as the instruments of this study. 262 students and 12 teachers were taken through random sampling from four disciplines: Marketing, Management, Human Resource Management, and Finance were selected as the participants of this study. The results revealed that there was a positive and significant correlation between student learning style and teacher teaching style $(r=.77, \mathrm{n}=262, p<.0005)$. The results obviously signified that awareness raising sessions should be set for students and teachers to understand the importance and implications of knowing their learning and teaching styles in business education environment. Shatalebi, Sharifi, and Javadi (2011) also examined the relationship between components of emotional intelligence and learning styles. The participants of this study were 320 B.A., M.A. and Ph.D. Students. The results of this study showed that among 15 components of emotional intelligence, only 3 components including intrapersonal relationships, impulse control, and happiness have been companionable with learning style. There was no relationship between other components of emotional intelligence and learning styles involve divergent, convergent, adaptive, and attractive. In a general explanation it can be understood that emotional intelligence signifies individuals' ability whereas learning style signifies individual preferences.

\section{Method}

Participants - The participants of this study were selected from one city, because of limitation and also this limitation was assisted to concordance of participants. The participants of this study were 90 Iranian EFL teachers who teaching English in Sistan and Bluchestan high schools and language institutes randomly selected by the researcher. The participants' ages varied between 25 to 44 years old.

Instrumentation Two kinds of instruments needed to conduct this study: Emotional Intelligence Questionnaire (Bar-On Emotional Quotient Inventory) and Teaching Styles Questionnaire (Grasha's Teaching Styles Inventory).

\subsection{Bar-On Questionnaire}

The Persian version of Bar-On Emotional Quotient Inventory was employed for this study to measure the teachers' emotional intelligence. It consists of five basic skills aimed to be measured in addition to 15 factor 
components. Intrapersonal is the first main skill consisting 30 items. It has 5 sub-branches; emotional self-awareness (6 items), assertiveness (6 items), self-regard (6 items), self-actualization (6 items) and independence (6 items). The second one is interpersonal and there are 18 items related to it. It has three sub-branches: empathy (6 items), interpersonal relationship (6 items) and social responsibilities (6 items). Adaptability is the third one and it has 18 items including problem solving ( 6 items), reality testing (6 items) and flexibility ( 6 items). The fourth one is stress management and it has 12 items, stress tolerance (6 items) and impulse control (6 items). The last one is general mood, it has 12 items include happiness and optimism, and both of them have (6 items) (Bar-On, 1997).

The responses of emotional intelligence questionnaire include (1.Very seldom or not true for me, 2. Seldom true for me, 3. Sometimes true for me 4. Often true for me, 5. Very often true for me or true for me (Bar-On, 1997). This Questionnaire includes 90 items and the Cronbach's Alpha reliability index was reported as .80 (Samouei, 2002). Dehshiri (2003) reported that the Persian version has generally good internal consistency, test-retest reliability, and construct validity. As he states, Cronbach's Alpha coefficient for the test was found to be .76 and the results of the factor analysis provided convincing support for the inventory hypothesized structure.

\subsection{Teaching Styles Inventory}

The Teaching Styles Inventory including 40 multiple choice items were administered to the participants. Each item is scored using a 7- point Likert scale form 1 (strongly disagree) to 7 (strongly agree). Mean score ranges for each of the sets of items related to the individual teaching styles were calculated. Then, the mean scores were categorized as low, moderate or high (based on the standards developed by Grasha (1996). Regarding this instrument, Grasha (1996) reports acceptable reliability (alpha $=0.68-0.75$ on individual scales, and alpha $=0.72$ for the entire test) and validity.

\subsection{Procedure}

The Bar-On questionnaire and teaching styles inventory were administered to 90 Iranian EFL teachers who teaching English in Sistan and Bluchestan high schools and language institutes. The questionnaires were administered in two sessions. First, Bar-On questionnaire was administered to EFL teachers. They had an opportunity of two days to complete it. Then, teaching styles inventory was distributed among teachers to complete it in two days. After collecting the data, the researcher analyzed the data and extracted the results by using SPSS.

\subsection{Data analysis}

The data collected was analyzed using the Statistical Package for Social Science (SPSS). For the first hypothesis, a Pearson-product moment correlation coefficient was employed to distinguish if the relationship between Iranian EFL teachers' emotional intelligence and their teaching styles is statistically significant or not. For the second hypothesis, Multiple-regression was used to investigate any component of emotional intelligence can act as predictors for Iranian EFL teachers' teaching styles.

\section{Results}

Question 1: Is there any statistically significant relationship between Iranian EFL teachers' emotional intelligence and their teaching styles?

To answer this research question, Pearson Product- Moment Correlation was employed. For computing Pearson $\mathrm{r}$, emotional intelligence has been considered as an independent variable and teaching styles as a dependent variable. According to Table 1, by computing the correlation, it can be understood that there was a strong positive and significant correlation between Iranian EFL teachers' emotional intelligence and their teaching styles. Results showed that emotional intelligence was significantly correlated to teaching styles, with 
The relationship between Iranian EFL teachers' emotional intelligence and their teaching styles

the observed value of Pearson $r=0.159$ at the 0.05 level of significance. This strong positive and significant value of $r$ implies that teachers' emotional intelligence has a positive and significant relationship with their teaching styles.

Table 1

Correlation between emotional intelligence and teaching styles

\begin{tabular}{cc}
\hline Emotional intelligence & Teaching styles \\
\hline$r$ & $0.159^{* *}$ \\
Sig & 0.022 \\
$N$ & 90 \\
\hline Note. ${ }^{* *}$ Correlation is significant &
\end{tabular}

This correlation results showed a statistically significant relationship between Iranian EFL teachers' emotional intelligence and their teaching styles.

Question 2: Can any component of emotional intelligence act as a predictor for teachers' teaching styles (as a whole concept)?

Table 2 shows descriptive statistics of components of emotional intelligence.

Table 2

Descriptive statistics of components of emotional intelligence

\begin{tabular}{cccccc}
\hline Components & General mood & Adaptability & Intrapersonal & Interpersonal & Stress management \\
\hline$N$ & 90 & 90 & 90 & 90 & 90 \\
$M$ & 3 & 3.6 & 3.9 & 4.3 & 3.4 \\
$S D$ & 0.725 & 0.681 & 0.718 & 0.733 & 0.940 \\
Min. & 2 & 2 & 2 & 3 & 2 \\
Max. & 4 & 5 & 5 & 5 & 5 \\
\hline
\end{tabular}

According to Table 2, mean score of general mood of emotional intelligence is 3 and SD of general mood is 0.725 , mean score of adaptability component of emotional intelligence is 3.6 and SD of adaptability is 0.681 , and mean score of stress management is 3.4 and SD of stress management is 0.940 , mean score of intrapersonal component is 3.9 and SD of intrapersonal is 0.718 and mean score of interpersonal component is 4.3 and SD of interpersonal is 0.733 . While, Table 3 shows regression of components of emotional intelligence and also, Table 4 shows regression of each components of emotional intelligence.

\section{Table 3}

Regression of components of emotional intelligence

\begin{tabular}{cccc}
\hline$R$ & $R^{2}$ & $F$ & Sig. \\
\hline 0.621 & 0.385 & 61.002 & 0.000 \\
\hline
\end{tabular}

\section{Table 4}

Regression of each components of emotional intelligence

\begin{tabular}{ccccccc}
\hline components & fixed value & general mood & adaptability & stress management & intrapersonal & Interpersonal \\
\hline B & 0.341 & 0.043 & 0.143 & 0.108 & 0.231 & 0.276 \\
T & 2.175 & 1.374 & 3.270 & 2.288 & 4.034 & 4.985 \\
Sig. & 0.007 & 0.170 & 0.001 & 0.023 & 0.000 & 0.000 \\
\hline
\end{tabular}

As can be seen in Table 3, total value of regression model is confirmed $(p=0.000<0.05)$. In Table 4, coefficients of each of dependent variables existent in regression analysis are mentioned. Based on the obtained information, the significant value of the general mood component is higher than the meaningful level of the determined (0.05), so this component does not have a role in predicting the variance of English teachers' teaching styles and is omitted from regression equation. According to the amount of B in Table 4, interpersonal 
component $(\mathrm{B}=0.27, p=0.000<0.05)$, the components of intrapersonal $(\mathrm{B}=0.23, p=0.000<0.05)$, adaptability $(\mathrm{B}=0.14, p=0.001<0.05)$ and stress management $(\mathrm{B}=0.10, p=0.02<0.05)$, could act as the predictors according to their order of importance. Four components of emotional intelligence (interpersonal, intrapersonal, adaptability and stress management), can act as predictors for teachers' teaching styles.

\section{Discussion}

Studies showed that emotional intelligence training has a significant impact on physical and mental problems such as somatic complaint, aggression, depression, anxiety and promote emotional self-awareness stress management. Teaching styles (which often reflect teachers' views on teaching and learning and their preferred behavior) have also received a considerable degree of attention within the educational literature over the past two decades. As stated pervious, the finding of data analysis revealed that there was a positive and significant relationship between Iranian EFL teachers' emotional intelligence and their teaching styles $\mathrm{r}(88)=$ $0.159, p<0.05$ (see Table 1). It indicated that Iranian EFL teacher's emotional intelligence was strongly correlated to their teaching styles and teachers who had more emotional intelligence used better teaching styles and those teachers who had good emotions behaved in a good way with their students and also employed good and appropriate teaching styles. The results of this study can emphasize the accidence with previous studies as stated in literature review.

The results of this study affirmed the finding of Azizian and Samadi (2011) determined the relationship between emotional intelligence (EI) and self-efficacy of the staff of the Hamedan Branch of Islamic Azad University. The results of this study revealed that there was a positive significant correlation between emotional intelligence (EI) and self-efficacy. Also it was understood that there was a positive significant correlation between self-awareness and self-efficacy and a positive significant correlation between self-control and self-efficacy. Furthermore, a positive significant correlation was explored between intimacy and self-efficacy and a positive significant correlation existed between social skills and self-efficacy. Shakib and Barani (2011) investigated the relationship between Iranian high school students' EQ (Emotional Quotient) level and their level of language proficiency. The participants of this study were 130 high school students in Gorgan. The instruments of this study were Nelson Proficiency Test and EQ Test. After homogenizing the scores of participants was decrease to 84. After that relationship between EQ scores and language proficiency scores were considered by using Pearson coefficient correlation. The results of this study showed that there was reliable and significant relationship between language proficiency and emotional intelligence.

Besides, the relationship between students' EQ level and their level of language proficiency was stronger in females than males. Gürol, Ozercan, and Yalcin (2010) examined the relationship between pre-service teachers' emotional intelligence and their self-efficacy. In addition, pre-service teacher differences on EI and self-efficacy beliefs were also investigated in this study by considering the gender of participants. The participants of present study were pre-service teachers who were selected from education faculty in Firat University. The results attained through using Pearson Product-Moment Correlation demonstrated that there was a positive significant correlation between perceived EI and self-efficacy $(r=0.5)$. This study supplied no support for gender differences in EI and self-efficacy. Pieterse and Quilling (2011) examined the impact of self-developed versus other-person-developed digital stories on emotional intelligence in learners, in Durban, South Africa.

Participants of this study were four classes each of Grade 9's and Grade 10's. Experimental groups were exposed to an accurate digital story power containing making by their own, watching peer-created and public digital stories. Non-experimental classes practiced no involvement. The SSEIT trait emotional intelligence test administered to pre-test, midway, post-test and one school term after the end of the intervention, permitting longitudinal tracking of emotional intelligence test results. Results showed the impact of the making of digital story- telling, watching of peer and public digital stories on trait EI. It also signified how qualitative data presents more immediate information than quantitative data from the SSEIS test. However, the real writing of the test has revealed to be critical in pupils' evaluations of their experiences. The results of this study demonstrated 
The relationship between Iranian EFL teachers' emotional intelligence and their teaching styles

teachers are able to proficiently use tools to encourage trait EI in the classroom.

Ebrahimi Koohbanani (2013) determined the relationship between spiritual intelligence (SI) and emotional intelligence with life satisfaction (LS) among talented female high school students in Birjand. For this goal, 123 students were elected considering the Simple Sampling Method. The results of this discovered that there is generally no meaningful relationship between SI and LS, but there was a meaningful relationship between EI and LS. The results of regression analysis illustrated that "Moral Virtue" in SI and "Appraisal \& Expression of Emotion" and "Regulation of Emotion" in EI is meaningful predictors for LS. Also SI together with EI has a meaningful relationship with LS. By evaluating the results of these five studies and this study it was concluded that there was a significant relationship between emotional intelligence and language learning and emotional intelligence was a significant skill for teachers to develop their language learning and also improve their choosing of appropriate teaching styles in their classroom.

The analysis of results showed that components of emotional intelligence act as a predicators of teaching styles. Based on the obtained information, the significant value of the general mood component is higher than the meaningful level of the determined (0.05), so this component does not have a role in predicting the variance of English teachers' teaching styles and is omitted from regression equation. According to the amount of B in Table 4 , interpersonal component $(\mathrm{B}=0.27, p=0.000<0.05)$, the components of intrapersonal $(\mathrm{B}=0.23, p=0.000<$ $0.05)$, adaptability $(\mathrm{B}=0.14, p=0.001<0.05)$ and stress management $(\mathrm{B}=0.10, p=0.02<0.05)$, could act as the predictors according to their order of importance. Four components of emotional intelligence (interpersonal, intrapersonal, adaptability, and stress management), can act as predictors for teachers' teaching styles. The results of this study were affirmed the results of this study as mentioned in literature review.

Shatalebi, Sharifi, and Javadi (2011) examined the relationship between components of emotional intelligence and learning styles. The participants of this study were 320 B.A., M.A. and Ph.D. Students. The results of this study showed that among 15 components of emotional intelligence, only 3 components including intrapersonal relationships, impulse control, and happiness have been companionable with learning style. There was no relationship between other components of emotional intelligence and learning styles involve divergent, convergent, adaptive, and attractive. In a general explanation it can be understood that emotional intelligence signifies individuals' ability whereas learning style signifies individual preferences. By comparing the results of this study and present study it was showed that some components of emotional intelligence used more than the other components such as interpersonal, intrapersonal, stress management and adaptability employed more than the other components of emotional intelligence.

\section{Implications of the study}

This part of the study consists of the theoretical and pedagogical implications.

\subsection{Theoretical Implications}

Language teaching and learning in our country seem to suffer from several drawbacks and problems; clarifying even a small part of all those problems may end up with developing solutions to partially help the situation. The present study focused on the significance of teachers' emotional intelligence and their teaching styles and also, identified the components of emotional intelligence which could act as predictors for teaching styles. The obtained findings of this study showed that the emotional intelligence had a significant relationship with teaching styles. It was revealed that moving along the continuum of emotional intelligence from interpersonal, intrapersonal, adaptability and stress management directly connected to teaching styles.

Hargreaves (1998, p. 835) has acknowledged that "emotions are at the heart of teaching", and that "good teaching is charged with positive emotion". Teaching as a profession has high rates of stress and high burnout (Kokkinos, 2007; Naring, Briet, \& Brouwers, 2006). Brackett, Patti, Stern, Rivers, and Elbertson (2009, p. 336) continue however that "teachers who are more skilled at regulating their emotions tend to report less burnout and 
greater job satisfaction". The findings of this study reveal that emotional intelligence of Iranian EFL teachers positively and significantly correlates to their teaching styles on one hand, and act as a predictor for Iranian EFL teachers' teaching styles, on the other hand. Emotional intelligence of EFL teachers should be enhanced because emotions are at the heart of teaching and good teaching engaged with good emotions and also those teachers who have good emotions, also have good teaching styles and behave in a good way with their students.

\subsection{Pedagogical Implications}

Bar-On (1997) acknowledged that emotional intelligence is an arrangement of personal, emotional, and social skills and competencies that influence one's ability to be successful in dealing with natural demands and difficulties, and directly influence one's overall psychological well-being. On the other hand, one's knowledge, skills, and overall intelligence must be augmented by the ability to comprehend, distinguish, and manage emotions. Meanwhile, Mayer, Salovey, and Caruso (1997) recommend that emotional intelligence is not place at first, but can be urbanized through teaching and education. In addition, emotions manipulate a crowd of cognitive processes, such as attention, perception, memory, decision making, and social judgments (Planalp \& Fitness, 1999). Elder (1997) noted that emotions play an essential role in educations. Ability to learn context, so emotions can assist learning. How a student employs emotions may also influence his/her ability to learn. Furthermore, emotions provide people with preceding information about themselves and how they talk to the others. Emotions are important to education; they drive attention, which drives learning and memory (Sylwester, 1994).

The findings of this study may be useful for education authorities, school managers and students. It was found that emotional intelligence would help EFL teachers to use the most appropriate teaching styles in their classroom. Emotional intelligence can increase teachers' ability in use different teaching styles in their classroom in order to facilitate students' language learning, because learning is an emotional process, so emotional intelligence is an important element in students' educational system. This study encourages education authorities and school managers to consider the emotional intelligence as an effective element for academic and career success. Education authorities can consider the results of this study for recruiting more effective teachers. School managers also benefit from the findings of this study to consider them in promoting teachers with more successful teaching styles to elevate motivations among English teachers in schools.

\section{Conclusion}

The present study was investigated to find out if there is any statistically significant relationship between Iranian EFL teachers' emotional intelligence and their teaching styles. The components of emotional intelligence that act as predictors for Iranian EFL teachers' teaching styles were explored. The findings of this study revealed that there was a significant relationship between the teachers' emotional intelligence and their teaching styles. With regard to the Multi-regression test, general mood component was higher than the meaningful level of the determined (0.05), so this component did not have a role in predicting the variance of English teachers' teaching styles and is omitted from regression equation. Four components of emotional intelligence (interpersonal, intrapersonal, adaptability and stress management), could act as predictors for teachers' teaching styles. It signified that teachers with more emotional intelligence are more successful and also use the best and most appropriate teaching style in their classroom. In conclusion, emotional intelligence is a significant element in educational system, which affects choosing the appropriate teaching style in the classroom and also helps the teachers to be more successful in their career.

Acknowledgement: I desire to convey my appreciation first of all to the kindhearted God, and afterward to my professor Dr. Giti Mosapour Negari, who assisted me throughout my thesis and furthermore, and most of all, thanks also my family. 


\section{References}

Ahuja, A. (2011). Impact of emotional intelligence on performance of call centers executives. IRFM, 1 (5), 223-229.

Amir, R., Mohd Jelas, Z., \& Rahman, S. (2011). Learning styles of university students: Implications for teaching and learning. World Applied Sciences Journal, 14, 22-26.

Azizian, S., \& Samadi, A. (2011). Study of relationship between emotional intelligence (EI) and self-efficacy the case of the staff of the Hamedan Branch of Islamic Azad University. Procedia - Social and Behavioural Sciences, 8(3), 54-61.

Bar-On, R. (1997). Bar-On emotional quotient inventory (EQ-I): Technical manual. Toronto: Multi- Health Systems.

Boud, D., Keogh, R., \& Walker, D. (1985). Reflection: Turning experience into learning. New York: Nichols Publishing.

Brackett, M. A., Patti, J., Stern, R., Rivers, S., Elbertson, N., Chisholm, C., \& Salovey, P. A. (2009). Sustainable skill based approach to developing emotionally literate schools. MI: Humanics.

Brown, H. D. (2007). Teaching by principles: An interactive approach to language pedagogy (3rd ed.). White Plains: Pearson.

Canfield, A. A. (1976). Leaning styles inventory. Ann arbor, MI: Humanics media.

Cooper, T.C. (2001). Foreign language style and personality. Foreign Language Annals, 34, 301-16. http://dx.doi.org/10.1111/j.1944-9720.2001.tb02062.x

Cotton, K. (2000). The schooling practices that matter most. Alexandria, VA: Association for Supervision and Curriculum Development.

Daniels, D. H., \& Perry, K. E. (2003). Learner-centered according to children. Theory into Practice, 42(2), 102-109. http://dx.doi.org/10.1207/s15430421tip4202_3

Dehshiri, R. (2003). The reliability and validity of EQ-I in Iran's con-text. Unpublished master's thesis, Allame Tabatabai University, Tehran, Iran.

Ebrahimi Koohbanani, M. (2013). The relationship between spiritual intelligence and emotional intelligence with life satisfaction among Birjand gifted female high school students. Procedia - Social and Behavioral Sciences, 84, 314-320. http://dx.doi.org/10.1016/j.sbspro.2013.06.558

Elder, L. (1997). Critical thinking: The key to emotional intelligence. Journal of Developmental Education, 21(1), 40-41.

Felder, R. M., \& Spurlin, J. E. (2005). Applications, reliability and validity of the index of learning styles. International Journal of Engineering Education, 21(1), 103-112.

Grasha, A. F. (1996). Teaching with style: a practical guide to enhancing leaning by understanding teaching and learning style. Pittsburgh: Alliance Publishers.

Gürol, A., Özercan, M., \&Yalçın, H. (2010). A comparative analysis of pre- service teachers’ perceptions of self-efficacy and emotional intelligence. Procedia-Social and Behavioral Sciences, 2, 3246-3251. http://dx.doi.org/10.1016/j.sbspro.2010.03.496

Hargreaves, A. (1998). The emotional practice of teaching. Teaching and Teacher Education, 14(8), 835-854. http://dx.doi.org/10.1016/S0742-051X(98)00025-0

Hargreaves, A. (2000a). The emotional geographies of teaching. Paper presented at the annual meeting of the American educational research association, New Orleans, LA.

Hargreaves, A. (2000b). Mixed emotions: Teachers' perceptions of their interactions with students. Teaching and Teacher Education, 16, 811-826. http://dx.doi.org/10.1016/S0742-051X(00)00028-7

Hargreaves, A., \& Tucker, E. (1991). Teaching and guilt: Exploring the feelings of teaching. Teaching \& Teacher Education, 7(5-6), 491-505. http://dx.doi.org/10.1016/0742-051X(91)90044-P

Hussain, N., \& Ayub, N. (2012). Learning styles of students and teaching styles of teachers in business education: A case study of Pakistan. Procedia - Social and Behavioral Sciences, 69, 1737-1740. http://dx.doi.org/10.1016/j.sbspro.2012.12.122

Joyce, B., \& Weil, M. (1986). Models of teaching (3rd ed.). Englewood Cliffs, NJ: Prentice-Hall. 
Mousapour, G., \& Khorram, A.

Khandaghi, M. A., \& Farasat, M. (2011). The effect of teacher's teaching style on students' adjustment. Procedia Social and Behavioral Sciences,_1(15), 1391-1394. http://dx.doi.org/10.1016/j.sbspro.2011.03.299

Kokkinos, C. M. (2007). Job stressors, personality and burnout in primary school teachers. British Journal of Educational Psychology, 77(1), 229-243. http://dx.doi.org/10.1348/000709905X90344

Mayer, J. D., Salovey, P., \& Caruso, D. R. (1997). The emotional IQ test (CD Rom). Needham, MA: Virtual Knowledge.

McCaughtry, N. (2004). Emotional dimensions of a teacher's pedagogical content knowledge: Influences on content, curriculum, and pedagogy. Journal of Teaching in Physical Education, 23(1), 30 -47.

Mckeachie, W. (1994). Teaching tips: A guide book for the beginning college teacher (9th ed.). Lexington, MA: Heath.

Mewborn, D. (2001). Promoting equity in mathematics classrooms. Middle School Journal, 32(3), 31-35.

Naring, G., Briet, M., \& Brouwers, A. (2006). Beyond demand-control: Emotional labor and symptoms of burnout in teachers. Work \& Stress, 20(4), 303-315. http://dx.doi.org/10.1080/02678370601065182

Pieterse, G., \& Quilling, R. (2011).The impact of digital story-telling on trait emotional intelligence (EI) amongst adolescents in South Africa - a case study. Procedia - Social and Behavioral Sciences, 28, 156-163. http://dx.doi.org/10.1016/j.sbspro.2011.11.031

Planalp, S., \& Fitness, J. (1999). Thinking/feeling about social and personal relationships. Journal of Social and Personal Relationships, 16(6), 731-750. http://dx.doi.org/10.1177/0265407599166004

Rahimi, M., \& Nabliou, Z. (2010). Iranian EFL teachers' effectiveness of instructions behavior in public and private high schools Asia. Pacific Education Review, 12, 67-78.

http://dx.doi.org/10.1007/s12564-010-9111-3

Rosiek, J. (2003). Emotional scaffolding. Journal of Teacher Education, 54(5), 399-412. http://dx.doi.org/10.1177/0022487103257089

Salovey, P., \& Mayer, J. D. (1990). Emotional intelligence. Imagination, Cognition and Personality, 9,185-211. http://dx.doi.org/10.2190/DUGG-P24E-52WK-6CDG

Samouei, R. (2002). Emotional quotient inventory. Esfahan: Ravan Tajhize Sina.

Seldin, P. (1984). Changing practices in faculty evaluation: A critical assessment and recommendations for improvement. San Francisco: Jossey-Bass.

Shakib, S., \& Barani, G. (2011). The relationship between emotional intelligence and language proficiency of Iranian high school students. Procedia - Social and Behavioral Sciences, 30, 1603-1607. http://dx.doi.org/10.1016/j.sbspro.2011.10.311

Shatalebi, B., Sharifi, S., \& Javadi, H. (2011). An integrative teaching model in the globalization era with a teaching technology orientation. Procedia - Social and Behavioral Sciences, 31(1), 8-12.

Sylwester, R. (1994). How emotions affect learning. Educational Leadership, 52(2), 60-65.

Yilmaz, H., \& Gavas, P. (2008). The effect of teaching practice on pre service elementary teachers' science teaching efficacy and classroom management beliefs. Eurasia Journal of Mathematics, Science and Technology Education, 4(1), 45-54. 